\title{
PERFORMANCE EVALUATION OF SPRINKLER IRRIGATION SYSTEM AT MAMBILLA BEVERAGE LIMITED, KAKARA-GEMBU, TARABA STATE-NIGERIA
}

\author{
F. G. Ngasoh ${ }^{1}$ C. C. Anyadike ${ }^{2,}{ }^{*}$, C. C. Mbajiorgu ${ }^{3}$ and M. N. Usman ${ }^{4}$ \\ 1, 2,3,4 DEPT. of Agricultural \& BIORESOURCES ENGINEERING, UNIV. OF NigERIA, NSUKKA ENUGU STATE. NIGERIA \\ E-mail addresses:1 felix.ngasoh.pg77013@unn.edu.ng, 2'chinenye.anyadike@unn.edu.ng, \\ ${ }^{3}$ constantine.mbajiorgu@unn.edu.ng,4makhaiusman@yahoo.co.uk
}

\begin{abstract}
Irrigation systems are designed to achieve a desired efficiency which in turns improve food productivity. This paper evaluated the Kakara Tea Irrigation System (KTIS) based on its coefficient of uniformity CU, delivery performance ratio (DPR), irrigation productivity (IP), labour requirements and water quality. Standard procedure was used for the evaluation. Christiansen's equation was used to compute CU. EDTA and flame photometer methods were used to analyse water quality. The result indicated that KTIS has a CU of 90.9\%, DPR of 0.79 which indicated an efficiency of 79\%. Sprinkler discharge rate was $1.21 / \mathrm{s}$ and application rate was $7.5 \mathrm{~mm} / \mathrm{hr}$. It is capable of irrigating $41.1 \mathrm{ha} /$ day with an average irrigation cycle of 9days and irrigation productivity of $2613.7 \mathrm{~kg} / \mathrm{ha}$. Total irrigation production contributes $68.6 \%$ to the annual production; case study of 2016 production record. The exchangeable cations analysis of Kakara irrigation System water indicates thus; $\mathrm{Na}\left(0.75 \mathrm{mgL}^{-1}\right)$, Ca $\left(1.01 \mathrm{mgL}^{-1}\right)$ and $\mathrm{Mg}\left(0.20 \mathrm{mgL}^{-1}\right)$ and Sodium adsorption ratio (SAR) value of (9.64mmoleL ${ }^{1}$ ), while the $\mathrm{pH}$ was 5.6. The result also indicated variation in discharge. Comparing the irrigation productivity (IP) with previous production records from 2011-2016 showed good irrigation performance trend of Mambilla Beverage Company irrigation scheme. However, the system is labour intensive since the laterals have to be moved after some period of time. The implementation or adoption of permanent laterals and risers will reduce manual labour demand. Variation in discharge can also be adjusted via use of uniform laterals, risers, and nozzles. This study further recommends an incorporation of a soil and water laboratory for the company to aid in monitoring the soil and water quality of the irrigation area.
\end{abstract}

Keywords: Tea, irrigation System, Performance Evaluation.

\section{INTRODUCTION}

According to [1] performance assessment has been an integral part of irrigation since man first started harnessing water to improve crop production. In the last decade according to [2]performance evaluation of irrigation scheme has specially been an important and active field of research. Improving the productivity of existing irrigation schemes, especially with the limited water and land resources availability has got an increasing attention for global increase in food security. In Nigeria, irrigation performance assessment has been given the highest priority among other research needed to solve the problems of irrigation development and management [3]. Improving the performance of irrigated agriculture is very important considering the serious constraints faced by irrigators due to water scarcity and the ensuing competition for water by other higher-valued industrial concerns and urban uses. A good starting point as identified by experts [3] is to assess the performance of available irrigation systems in order to identify areas of lapses and make amend [4]. Evaluation is an indispensable tool in irrigation project management since it enables irrigation managers to measure and determine actual performance, and the factors that are responsible for low or less performance. The potentials of irrigation towards boosting agricultural production in Nigeria is enormous, considering the steady population increase and the variability and high temperature that draught especially the northern part of the country. Agriculture depending on rainfall in the southern and eastern part of the country has failed to produce enough food, and with increasing rainfall variability, productivity or rained agriculture is expected to diminish. To meet the increasing demand for food in Nigeria, significant investment in irrigation is needed and should be encouraged. To encourage and boost agricultural productivity through irrigation, it is important that the few irrigated arms in Nigeria, produce optimally at the 
most minimum water usage. Improving the performance of existing irrigation farms will not only boost production at reduced cost but it will encourage growers or farmers into irrigation agriculture thereby bridging the food security gap in Nigeria.

The Kakara Tea Irrigation agriculture project located at the Mambila Plateau in Sarduna Local Government Area of Taraba State is one of the major irrigation projects in Nigeria. Improving the performance of this irrigation project through constant evaluation is considered a key issue in addressing the need for increased productivity of irrigated lands under pressure of water resource as forecasted by [5]. This paper therefore aimed at evaluating the performance of the Kakara Tea Irrigation project to ascertain the actual amount of water applied to the grown tea as opposed to the potential. This study collates invaluable data which will help to update the existing data base and guide the growers against failure in the future.

\section{METHODOLOGY}

\subsection{Description of the Kakara Tea Irrigation Project}

The Mambilla Plateau, where the Kakara Tea Irrigation project is located is between latitudes $6^{0} .43^{\prime}$ to $6^{\circ} .71^{\prime} \mathrm{N}$ and longitude $11^{0} .15^{\prime}$ to $11^{0} 25^{\prime} \mathrm{E}$. It has a total land mass of $3,765.2 \mathrm{~km}^{2}$ for farming [6]. Fig.1 shows the Kakara village via Google earth.

The monthly rainfall records of the area for 2016 are shown in Table1. Rainfall is higher in August and September compared to other months. High temperature is observed during the dry season (January to March and early April sometimes). Sunshine hours are limited considering the plateau with high amount of rainfall. The highest sunshine hours are in January and December (see Table 1). The relative humidity was observed to be low compared to periods of high sunshine hours; hence these are the periods in which moisture of the soil is supplemented with irrigation so as to aid the crop growth and enhance its productivity.

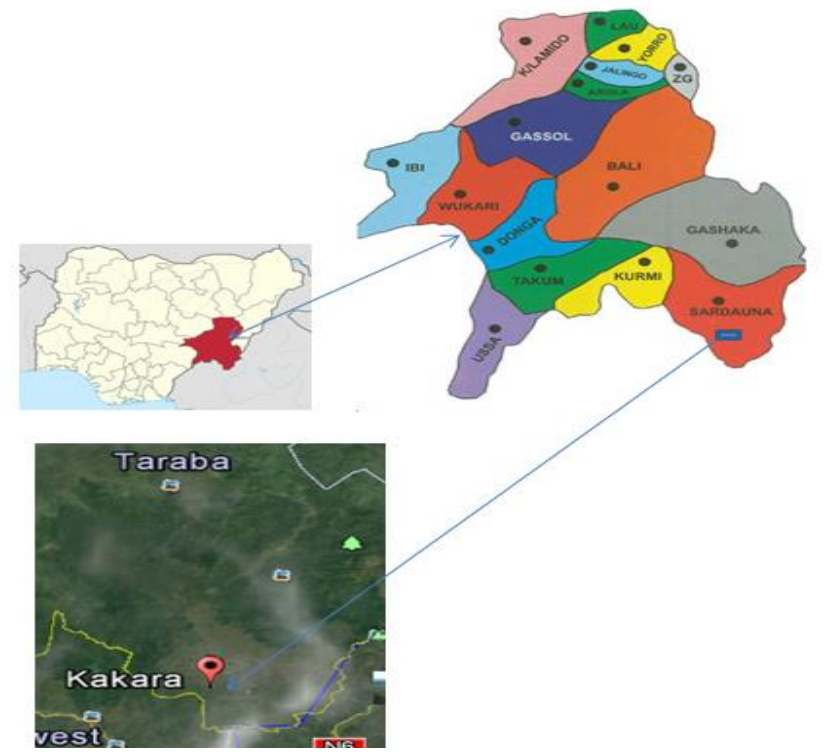

Figure 1: Kakara Village via Google Earth

Tea, a flowering plant, belonging to the camellia (camelliasinesis) family, is the major crop grown at Kakara Tea Irrigation Project. The tea is grown in a total landmass of 700 ha out of which 370 ha (52.9\%) is under irrigation. Tea is grown under a maximum monthly temperature of $30.0^{\circ} \mathrm{C}$ and minimum monthly temperature of $11.2^{\circ} \mathrm{C}$ [7]. Temperature above $33{ }^{\circ} \mathrm{C}$ or below $10{ }^{\circ} \mathrm{C}$ endangers the tea plants causing reduction in the rate of leaf growth [8]. The source of water for Kakara Tea Irrigation system (KTIS) is the Tunga dam (also known as Sijin Dam) located at approximately 20 $\mathrm{km}$ away from the main factory. The dam has an embankment crest level of $1582 \mathrm{~m}$ above the sea level, and a total volume of $10,260,000 \mathrm{~m}^{3}$ (see plates 1a \& 1b).

Table 1: Metrological Data of Kakara from January to December, 2016

\begin{tabular}{|c|c|c|c|c|c|c|}
\hline \multirow{2}{*}{ Month } & \multirow{2}{*}{ Rainfall (MM) } & \multirow{2}{*}{$\begin{array}{r}\text { No of } \\
\text { Rainfall }\end{array}$} & \multicolumn{2}{|c|}{ Average Temperature } & \multirow{2}{*}{$\begin{array}{r}\text { Average Relative } \\
\text { Humidity (\%) }\end{array}$} & \multirow{2}{*}{$\begin{array}{r}\text { Average } \\
\text { Sunshine (Hrs) }\end{array}$} \\
\hline & & & $\operatorname{Max}\left({ }^{0} \mathrm{C}\right)$ & $\operatorname{Min}\left({ }^{0} \mathrm{C}\right)$ & & \\
\hline Jan. & 0.0 & N.R & 29.0 & 13.7 & 30 & 8.1 \\
\hline Feb. & 11.5 & 2 & 29.8 & 18.5 & 25 & 7.0 \\
\hline Mar. & 52.8 & 4 & 30.9 & 17.9 & 19 & 5.8 \\
\hline April & 150. & 14 & 28.5 & 19.7 & 62 & 5.0 \\
\hline May & 169.3 & 19 & 25.0 & 19.2 & 76 & 4.0 \\
\hline June & 176.5 & 20 & 27.2 & 18.1 & 70 & 3.7 \\
\hline July & 273.0 & 25 & 25.8 & 17.7 & 72 & 3.5 \\
\hline Aug. & 347.9 & 27 & 23.0 & 11.9 & 73 & 5.0 \\
\hline Sept. & 339.4 & 26 & 23 & 10.9 & 73 & 4.6 \\
\hline Oct. & 277.8 & 20 & 26 & 16.8 & 60 & 7.0 \\
\hline Nov. & 162.1 & 13 & 25.9 & 18.0 & 63 & 7.6 \\
\hline Dec. & 9.0 & 1 & 28.3 & 18.7 & 58 & 8.4 \\
\hline
\end{tabular}


The farm level is $1464 \mathrm{~m}$ above the sea level. Hence, the water channelled to the tea farm is by gravity: since it has a head of $118 \mathrm{~m}$. The dam is also used for generation of power for the Mambilla Beverage Nigeria limited (MBNL), and staff residential area. It also supplies water for domestic purposes for the staff living at the company's estate, Kusuku and Kakara villages close by.

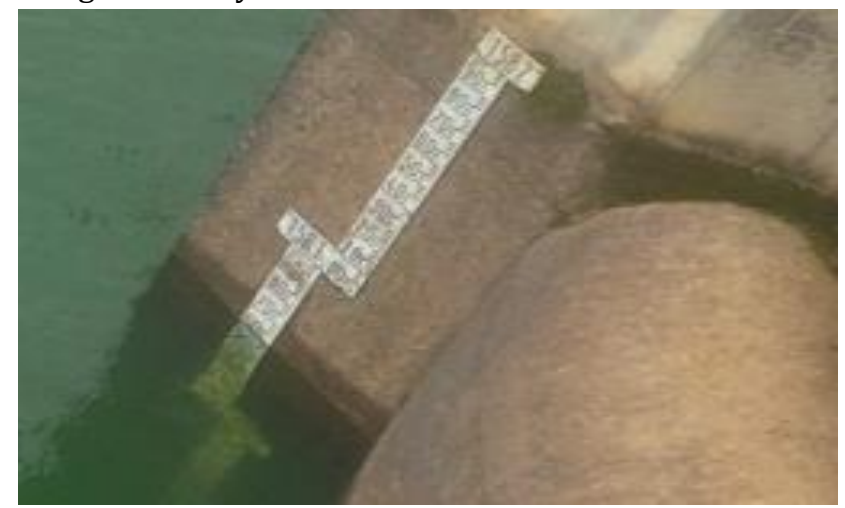

(a)

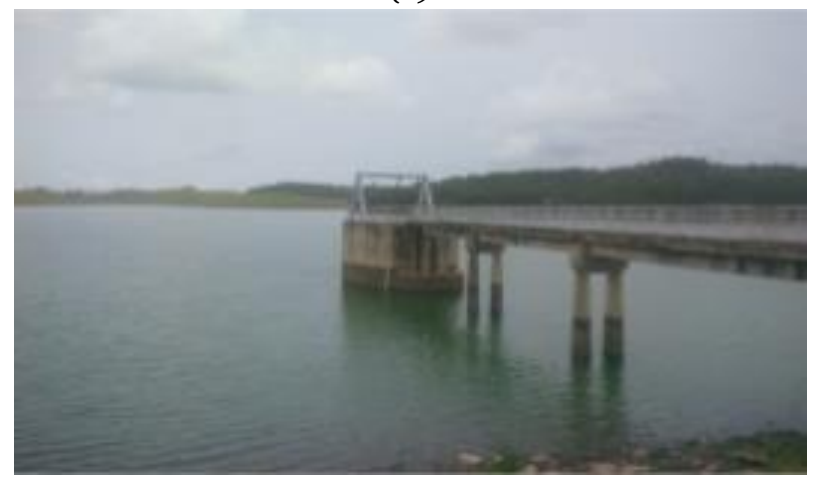

(b)

Plate 1: Tunga Dam

\subsection{Sprinkler Equipment Description}

The Kakara Tea Irrigation System (KTIS) practices the linear lateral move ("hope along") system of sprinkler irrigation. The water from the source enters the main pipe at the gate by gravity; the sub-main pipe is connected to divert the water into farm. The hydrants and valves are connected to the sub-main before it is connected to the laterals and risers to the sprinklers and water sprinkles out through the nozzles. The sprinklers were observed to be of divers make and sizes (Table 2). The sprinkler has dual nozzles sizes of $4.8 \times 3.2 \mathrm{~mm}$ and $4.4 \times 2.5 \mathrm{~mm}$. There are two different sizes of risers; 3 inches and 2 inches. The system does not require a pump as water diverted into the field flows by gravity. The gravity gives the system nozzle the required pressure, because the water head is $118 \mathrm{~m}$ (the difference between the water source level and the farm level is $1582 \mathrm{~m}-1464 \mathrm{~m}$ ).
Table 2: Sprinkler made, riser size and nozzle size

\begin{tabular}{lccc}
\hline \multirow{2}{*}{$\begin{array}{l}\text { Sprinkler } \\
\text { Made }\end{array}$} & \multicolumn{2}{c}{ Nozzles size } & \multirow{2}{*}{$\begin{array}{c}\text { Size of } \\
\text { Riser }\end{array}$} \\
\cline { 2 - 3 } & Large $(\mathrm{mm})$ & $\begin{array}{c}\text { Small Side } \\
(\mathrm{mm})\end{array}$ & \begin{tabular}{c} 
(Inches) \\
\hline Nelson
\end{tabular} \\
Somlo & 4.8 & 3.1 & 2 \\
Naan & 4.8 & 3.2 & 2 \\
Parrot & 4.4 & 2.5 & 2 \\
\hline
\end{tabular}

\subsection{Evaluation of Kakara Tea Irrigation System}

Evaluation is very important in establishing the performance of an irrigation system. Measurements are taken to ascertain the actual amount of water which is applied to the crop, as opposed to the potential [9]. According to [10], the overall performance of Irrigation relies on uniform application of water.

In evaluating the effectiveness of the "hope-along" (linear lateral move) Irrigation system used in Kakara Tea Irrigation project the guide given by $[11,12]$ was used. The parameters evaluated include annual cost of operating the system using the [13] method, the annual cost per hectare compared to annual returns per hectare; so as to measure economics, and labour requirement of the system, the application uniformity (coefficient of uniformity; a critical parameter [14] in ascertaining the effectiveness of the project. Energy was not considered in the evaluation, since water distribution is by gravity. The sprinkler design parameters were also considered. The irrigation water quality was also analysed based on the two major hazards; salinity and sodium hazard which was expressed as sodium absorption ratio. (SAR) as represented by Eqn. 1 [15].

$$
\mathrm{SAR}=\frac{\mathrm{Na}^{+}}{\sqrt{\frac{\mathrm{Ca}^{++}+\mathrm{Mg}^{++}}{2}}}
$$

\subsection{Field Experiments}

The study was carried out at the Kakara Tea Irrigation Project at Mambilla plateau in Taraba state. The field is a hilly terrain but well developed for irrigation purposes. The tests were carried out under moderate environmental conditions at an average wind speed of less than $5.4 \mathrm{~km} / \mathrm{hr}$. The soil type is loamy soil.

\subsubsection{Uniformity of Water Distribution}

The determination of the uniformity of water distribution of the hop-along sprinkler system was done according to [16] standards. An area of the field, bounded by three sprinklers (Fig.1) was mapped out. The sprinkler nozzle sizes were $4.4 \times 2.5 \mathrm{~mm}$ and $4.8 \times 3.1 \mathrm{~mm}$ whereas two different risers of 3 inches 
and 2 inches were used. The test procedure consisted of setting up a pattern of identical cylindrical cans of diameter $6.7 \mathrm{~cm}$ and height of $10.3 \mathrm{~cm}$, projected 5 inches above the ground level and distanced $6 \mathrm{~m}$ apart. The cans were arranged along the lateral line (Fig 1).

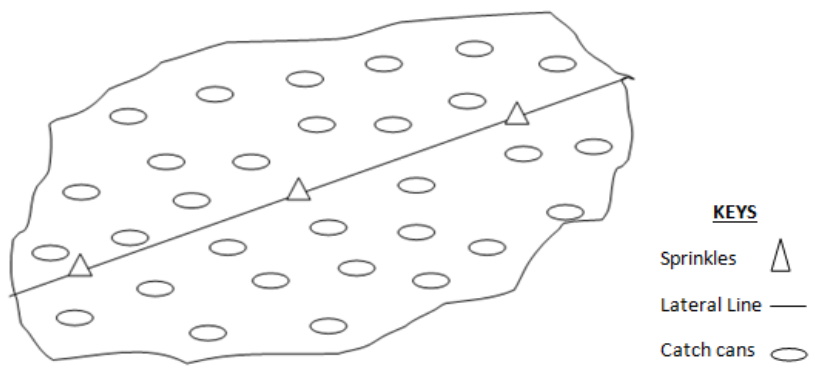

Fig. 1: Field Experiment Layout

Both lateral and sprinkler spacing is $24 \mathrm{~m}$ and radius of through is $18 \mathrm{~m}$. The sprinkler system was operated for a period of $90 \mathrm{~min}$ and the rates of discharge were recorded. This procedure was carried out in the evening hours to avoid disturbance by drifting air and also maintaining good overlapping of the sprinkling. The experimental results are presented in Table 3 . From the observed parameters presented in Table 3 , uniformity coefficient was computed using the Christiansen's equation (Eqn. 2).

According to [17] a coefficient of uniformity, CU $>84 \%$ is desirable. Arrangement styles that have the results less than this value should not be used.

$$
\mathrm{CU}=\left[1-\frac{\sum f \times(z-m)}{\sum f \times z}\right] \times 100
$$

Where: $\mathrm{Z}$ is the amount discharged in each catch can during test, $\mathrm{m}=\frac{\sum f \times z}{\sum f}$ is the Average discharge in can during test and $f$ is the frequency of cans.

\subsubsection{System Sprinkler Discharge Rate}

Sprinkler system capacity is one of the predetermining parameters in the evaluation of a sprinkler irrigation system. It is dependant of the system application rate. The sprinkler discharge test was carried out and compared with the calculated value using Eqn.3 [18]

$$
\mathrm{q}=\frac{S_{s} \times S_{l} \times R_{a}}{3600}
$$

\begin{tabular}{|c|c|c|c|c|}
\hline Observations, z (cm) & Frequency (f) & Discharge $\mathrm{f} \times \mathrm{z}(\mathrm{cm} / \mathrm{hr})$ & Mean Deviation (/z-m/) & $\mathrm{f} \times(/ \mathrm{z}-\mathrm{m} /)$ \\
\hline 0.65 & 1 & 0.65 & 0.1006 & 0.1006 \\
\hline 0.70 & 1 & 0.70 & 0.0506 & 0.0506 \\
\hline 0.80 & 2 & 1.60 & 0.0493 & 0.0986 \\
\hline 0.81 & 1 & 0.81 & 0.0593 & 0.0593 \\
\hline 0.63 & 1 & 0.63 & 0.1206 & 0.1206 \\
\hline 0.75 & 2 & 1.50 & 0.0006 & 0.0012 \\
\hline 0.72 & 1 & 0.72 & 0.0306 & 0.0306 \\
\hline 0.64 & 1 & 0.64 & 0.1106 & 0.1106 \\
\hline 0.67 & 1 & 0.67 & 0.0806 & 0.0806 \\
\hline 0.90 & 1 & 0.90 & 0.1493 & 0.1493 \\
\hline 0.73 & 1 & 0.73 & 0.0206 & 0.0206 \\
\hline 0.71 & 1 & 0.71 & 0.0406 & 0.0406 \\
\hline 0.69 & 1 & 0.69 & 0.0606 & 0.0606 \\
\hline 0.76 & 1 & 0.76 & 0.0093 & 0.0093 \\
\hline 0.84 & 1 & 0.84 & 0.0893 & 0.0893 \\
\hline 0.82 & 1 & 0.82 & 0.0693 & 0.0693 \\
\hline 0.79 & 1 & 0.79 & 0.0393 & 0.0393 \\
\hline 0.85 & 2 & 1.70 & 0.0993 & 0.1986 \\
\hline 0.69 & 1 & 0.69 & 0.0606 & 0.0606 \\
\hline 0.68 & 2 & 1.36 & 0.0706 & 0.1412 \\
\hline 0.74 & 1 & 0.74 & 0.0106 & 0.0106 \\
\hline 0.58 & 1 & 0.58 & 0.1706 & 0.1706 \\
\hline 0.86 & 1 & 0.86 & 0.1093 & 0.1093 \\
\hline 0.82 & 1 & 0.82 & 0.0693 & 0.0693 \\
\hline 0.73 & 1 & 0.73 & 0.0206 & 0.0206 \\
\hline \multirow[t]{2}{*}{0.88} & 1 & 0.88 & 0.1293 & 0.1293 \\
\hline & $\sum \mathrm{f}=30$ & $\sum \mathrm{f} \times \mathrm{z}=22.52$ & & $\sum \mathrm{f} \times(/ \mathrm{z}-\mathrm{m} /)=2.0426$ \\
\hline
\end{tabular}

Table 3: Parameter for computation of Coefficient of Uniformity 
In (3) $\mathrm{q}$ is the sprinkler discharge rate $(\mathrm{l} / \mathrm{s}), \mathrm{S}_{\mathrm{s}}$ is the sprinkler spacing $(\mathrm{m}), \mathrm{S}_{\mathrm{l}}$ is the lateral spacing $(\mathrm{m})$ and $\mathrm{R}_{\mathrm{a}}$ is the application rate $(\mathrm{mm} / \mathrm{hr})$. The capacity of the sprinkler determines the capability of the system and the irrigation cycle which is 9 days. The area of land irrigated per day was computed using Eqn.4 [19]

$$
\mathrm{A}=\frac{T_{a}}{I C}
$$

Where: A is Area of land irrigated per number of hours a day (ha/day), $\mathrm{T}_{\mathrm{a}}$ is the total irrigated land (ha) and IC is irrigation cycle (days)

\subsubsection{Delivering Performance Ratio (DPR)}

The delivery performance ratio being a measure of system performance was computed from the data generated for sprinkler discharge test; using equation 5, adopted from Molden and Gate as cited by [4]

$$
\mathrm{DPR}=\frac{\text { Actual discharge }}{\text { Required Discharged }}
$$

\subsubsection{Irrigation Productivity}

Every agricultural activity is geared toward improving productivity of the irrigated plot. Irrigation productivity (IP) was evaluated based on the production records (see Table 4) from 2011-2016 of Mambilla Beverage Company using Eqn. 6 [20].

$$
\text { I. P }=\frac{\text { Yield from plots under irrigation }}{\text { Hectares of plot under irrigation }}
$$

\subsubsection{Irrigation Water Quality.}

Six different samples of water were collected from three different points around the dam and stored in a clean one litre container for analysis. Standard buffer solution, pH-meter with glass electrode and thermometer were used to test for the $\mathrm{pH}$ level of the water [15]. Complexometric titration using Sodium salt of ethylene-diamine tetra-acetic acid (EDTA) reagent was used to determine Calcium and Magnesium ions $\left(\mathrm{Ca}^{++}\right.$and $\left.\mathrm{Mg}^{++}\right)$. Sodium was determined using flame photometer method [21]

\section{RESULTS AND DISCUSSION \\ 3.1 Results}

Table 5 presents the expected and obtained values of the evaluated parameters, while Table 6 presents the results obtained from analysis of cations presence and the corresponding Sodium Absorption Ratio (SAR) in the irrigation water.

\subsection{Discussion}

The coefficient of uniformity of Kakara Tea Irrigation system was observed to be $90.9 \%$ which is in conformity with [17] and [22] results but above that above that of [4] which was $86 \%$. This shows that the sprinkler system of irrigation at the study area is effective since the expected result is $85 \%$ and above. Based on the irrigation cycle which is averagely 9 days, it was observed that the system is capable of irrigating 41.1 ha of land per day. It would take the operator less number of days if more sprinkler equipment are acquired and installed. The sprinkler application rate was $1.2 \mathrm{~mm} / \mathrm{hr}$ based on the field experiment instead of $1.8 \mathrm{~mm} / \mathrm{hr}$ expected value. The decline in the value of the discharge may have resulted from the age, clogging or poor storage methods of some nozzles. The Delivery performance ratio, DPR was observed to be 0.79 from the experimented field data which indicated an efficiency of $79 \%$. This obtained efficiency agrees with the experimental results of $[11,12]$ on irrigation efficiencies of different sprinkler systems but dis agree with that of [4] which was 0.87. Based on the studies done by $[11,12]$, the sprinkler irrigation system of the research area is effective. This efficiency can as well be improved if sprinkler equipment are properly managed and replaced at due time

Fig. 2 presents the graph of sprinkler discharge variation. This variation is confined to the variation of nozzles' makes and sizes (see Table 2). Recalling Table 3 , the range (difference between maximum and minimum) of catch or discharge was $3.2 \mathrm{~mm}$ with minimum and maximum discharge of $5.8 \mathrm{~mm}$ and 9.0 mm respectively.

Table 4: Green Tea Harvested from Irrigated and Non-irrigated Area from 2011-2016

\begin{tabular}{cccc}
\hline Year & Green Tea (Kg) Non-Irrigated Area & Green Tea (Kg) Irrigated Area & Irrigation productivity (kg/ha) \\
\hline 2011 & 439,323 & 926,861 & $2,505.0$ \\
2012 & 458,066 & 898,833 & 2429.3 \\
2013 & 435,543 & 907,319 & 2452.2 \\
2014 & 378,593 & 887,832 & 2399.5 \\
2015 & 349,312 & 968,664 & 2618.0 \\
2016 & 442,650 & 967,063 & 2613.7 \\
\hline
\end{tabular}

Source: MBNL Production Records Book, (2016) 
Table 5: Results of Evaluation

\begin{tabular}{lcc}
\hline Parameters & $\begin{array}{c}\text { Required/Expected } \\
\text { value }\end{array}$ & $\begin{array}{c}\text { Obtained } \\
\text { value }\end{array}$ \\
\hline $\begin{array}{l}\text { Application rate } \\
\text { Delivery }\end{array}$ & $9.48 \mathrm{~mm} / \mathrm{hr}$ & $7.5 \mathrm{~mm} / \mathrm{hr}$ \\
$\begin{array}{l}\text { Performance } \\
\text { Ratio }\end{array}$ & 1 & 0.79 \\
$\begin{array}{l}\text { Sprinkler } \\
\text { discharge rate }\end{array}$ & $1.8 \mathrm{l} / \mathrm{s}$ & $1.2 \mathrm{l} / \mathrm{s}$ \\
$\begin{array}{l}\text { Uniformity } \\
\text { coefficient }\end{array}$ & $85 \%$ and above & $90.9 \%$ \\
$\begin{array}{l}\text { Irrigation } \\
\text { Productivity }\end{array}$ & - & 2613.7 \\
$\begin{array}{l}\text { Irrigated land per } \\
\text { day }\end{array}$ & - & $\mathrm{kg} / \mathrm{ha}$ \\
\hline
\end{tabular}

Table 6: Chemical Analysis Result of Tunga Dam for Kakara Tea Irrigation Project

\begin{tabular}{|c|c|c|c|c|c|}
\hline \multirow[t]{2}{*}{ YEARS } & \multirow[t]{2}{*}{$\begin{array}{l}\mathrm{pH} \\
\text { mean }\end{array}$} & \multicolumn{3}{|c|}{$\begin{array}{l}\text { Exchangeable } \\
\text { Cations }\left(\mathrm{mgL}^{-1}\right) \\
\text { mean value }\end{array}$} & \multirow[t]{2}{*}{ SAR(mmole/l) } \\
\hline & & $\mathrm{Na}^{+}$ & $\mathrm{Ca}^{++}$ & $\mathrm{Mg}^{++}$ & \\
\hline 1980 & 5.80 & 0.60 & 0.85 & 0.17 & 8.38 \\
\hline 2000 & 4.60 & 0.55 & 0.90 & 0.19 & 7.38 \\
\hline 2013 & 5.40 & 0.63 & 0.81 & 0.23 & 8.74 \\
\hline 2016 & 5.60 & 0.75 & 1.01 & 0.20 & 9.64 \\
\hline
\end{tabular}

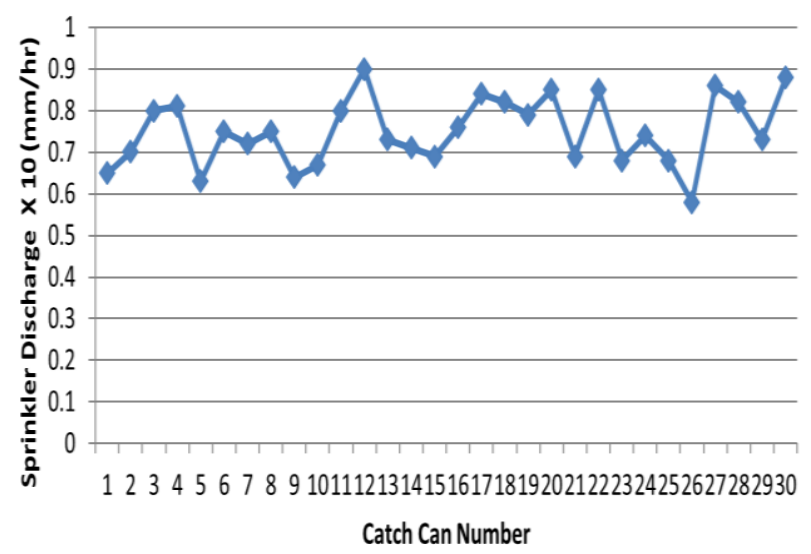

Fig. 2: Sprinkler Discharge Variation

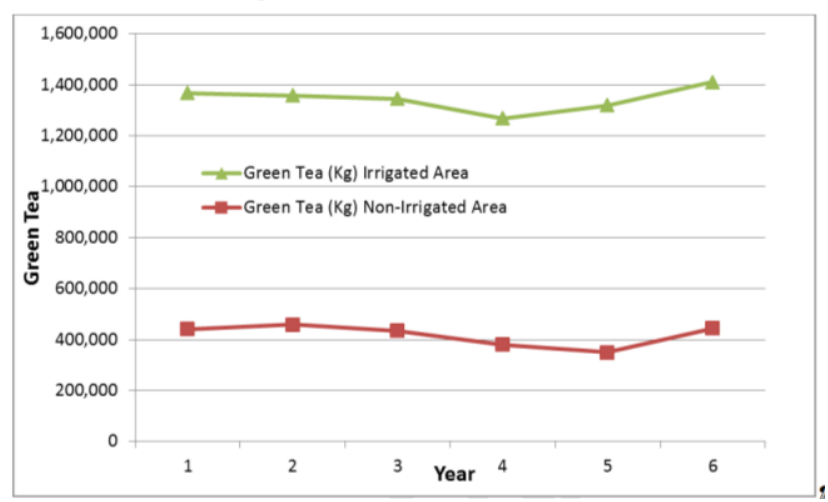

Fig. 3: Variation in irrigated and non-irrigated green tea leave from 2011-2016

\subsubsection{Irrigation Productivity:}

It was observed from computation value that irrigation productivity of Kakara Tea Irrigation System is 2613.7 $\mathrm{kg} / \mathrm{ha}$. This was computed based on 2016 total production output from irrigated area, which was $960,063 \mathrm{~kg}$. This contributed approximately $68.6 \%$ of the production as against $31.4 \%$ for non-irrigated land with landmass factor. Removing landmass as a contributing factor, 230 ha of irrigated land hitherto supersedes 230 ha of non-irrigated land by $15.24 \%$. Fig. 3 presents the graph of green tea production from both irrigated and non-irrigated land for six years. From this graph, it can be deduced that the aim of increasing yield via irrigation is highly achieved at the Kakara Tea Irrigation Project of the Mambilla Beverage Company Nigeria Limited.

\subsubsection{Chemical Characteristic of the water}

The water $\mathrm{pH}$ has the mean value of 5.60. Comparing this to it value from inception and intermediate researches, there have always been slight and insignificant changes due to human activities and grazing around the area. This result also indicates that the water is slightly acidic and may not be suitable for crops that are sensitive to acid water. As reported by [23], tea plant most satisfactory grow well within $\mathrm{pH}$ range of 4.0 and 6.0. Therefore, the water $\mathrm{pH}$ value is at a desirable range for the crop grown.

The exchangeable cations of the water used for irrigation at Kakara has mean value of $\mathrm{Na}\left(0.75 \mathrm{mgL}^{-1}\right)$, Ca $\left(1.01 \mathrm{mgL}^{-1}\right)$ and $\mathrm{Mg}\left(0.20 \mathrm{mgL}^{-1}\right)$ and the Sodium adsorption ratio (SAR) value of $\left(9.64 \mathrm{mmoleL}^{-1}\right)$. Comparing these values with the previous tests, there is no significant differences. Most likely, the little alterations are caused by human activity. Also considering the recommendations made by the [24] for irrigation water "Ca $\left(0-20 \mathrm{mgL}^{-1}\right), \mathrm{Mg}\left(0-5 \mathrm{mgL}^{-1}\right)$ and $\mathrm{Na}\left(0-40 \mathrm{mgL}^{-1}\right)$ and SAR (0-15 mmole/L)", the water source is non-alkaline as it is clearly indicated by the $\mathrm{pH}$ value. The SAR falls within the required range meeting the standard demand for irrigation water reported by [15]

\section{CONCLUSION AND RECOMMENDATION}

The $\mathrm{pH}$ and the exchangeable cations in the irrigation water used by Kakara Tea Irrigation Project (KTIP) is in conformity with irrigation water requirements standard [24]. The system also has good distribution uniformity, but if uniform sprinklers and nozzles sizes are used, it will improve the application uniformity of the system which will also increase irrigation 
productivity. Instead of KTIP to continue practicing "Hop-along" system of sprinkler irrigation, they should always mount sprinklers on all the risers to minimize labour requirement of the system.

This study further recommend government and the management of Mambilla Beverage company to endeavour to build soil and water laboratory to enable soil and water analysis within the company for the purpose of research and also to help them remain updated on the geo and hydro-information of the area to avoid gradual degradation of the land and contamination of water body. The management should also adapt the system of making use of the same size of nozzles instead of varying (Table 2). If they must use different sizes and mades of sprinklers, installation should be based on nozzle sizes or made.

\section{REFERENCES}

[1] Bos, M. G, Methodologies for assessing performance of irrigation and drainage management. Irrigation and Drainage Systems, 7(4): p. 231-261, 1994.

[2] Dejen, Z. A., Hydraulic and operational performance of irrigation schemes in view of water saving and sustainability: sugar estates and community managed schemes In Ethiopia: CRC Press/Balkema. 2015.

[3] Nwa, E. U. and P. Pradhan. Irrigation research priorities for Nigeria. in national seminar. University of Ilorin, Nigeria, 1993.

[4] Ahaneku, I. E., Performance evaluation of portable sprinkler irrigation system in Ilorin, Nigeria. Indian Journal of Science and Technology. 3(8): p. 853-857, 2010.

[5] FOA, Improving incentives to expand wheat production in Ethiopian, MAFAP policy brief \#9. 2013.

[6] GPS-Coordinate. Latitude and longitude of Mambila [cited 2017 25th May]; Available from: http://latitude.to/articles-bycountry/ng/nigeria/94562/mambila. 2017.

[7] CRIN., Cocoa Research Institute of Nigeria Handbook, in Manual: Kakara, Nigeria. 2008.

[8] Kamau, D. M., Productivity and Resources Use in Aging tea Plantation, Wageningen University: Wageningen. p. 181. 2008.

[9] Griffiths, B. and N. L. Lecler. Irrigation system evaluation. in South African Sugar Technologists Association.. South Africa Proceedings of South Africa Sugar Technologist Association, 2001.
[10] Rudnick, R. D. and S. Irmak, Irrigation Efficiency; Overview Steps in Irrigation Series.: p. 39-60, 2015.

[11] Paolini, O., National Engineering Handbook "Irrigation System Design" General Approach. 2059. 2005.

[12] Irmak, S., Odhiambo, L. O., KranzW. L. and Eisenhauer, D. E, Irrigation Efficiency, Uniformity and Crop Use Efficiency, U.o. Nebraska, Editor.: Lincoln, 2011.

[13] Israelsen, O. W. and V. E. Hansen, Irrigation Principles and Practices. John Wiley and Sons, Inc. Third Edition. p. 341., I. John Wiley and Sons, Editor. p. 341. 1962.

[14] Dudek, T. and R. T. Fernandez, Conducting Water Application Uniformity Evaluation for an Overhead Sprinkler Irrigation System in the Nursery of Michigan State University. 2013.

[15] Pawer, D. R., Randhe, D. B. Shaikh, M.Korder, A. K, Shinde, K. A. Yadav, M. P., Chavan, A. E. and Sapkale, V. M. Laboratory Testing Procedure for Soil and Water Sample Analysis. Water Resources Department, , in Directorate of Irrigation Research and Development,: Pune. p. 130. 2009.

[16] ASABE-S4.361, Standards engineering practices and data. 56th ed. Amer. Soc. Agri. Bio. Engineers., America: St, Joseph, MI, 2009.

[17] Keller, J. and R. D. Bliesner, Sprinkle and Trickle Irrigation, New York, USA: Van Nostrand Reinhold. 652. 1990.

[18] Huffman, R. L., et al., Soil and water conservation Sixth Edition ed: Published by ASABE. 403-433. 2011.

[19] Savva, A. P. and K. Frenken, Irrigation Manual: Planning, Development, Monitoring and Evaluation of Irrigated Agriculture with Farmer Participation. Vol. 2. 2002.

[20] Machibya, M., challenging Established Concept of Irrigation efficiency in a Water Scarce River Basin: A case Study of Usangu Basin, University East Anglia: Tanzania. 2003

[21] Black, C. A., Method of Soil Analysis, in American Society of Agronomy Inc, Madison: USA. 1965.

[22] Ramazan, T., Suheri, S, Ciftci, N and Acar, B, Performance of sprinkler irrigation in a semi-arid area. . Pakistan Journal of Biological Science. 8(1): p. 97-103, 2005.

[23] Othieno, C. 0., Tea Soils: Cultivation to consumption., London: Chapman and Hall. 1992.

[24] USDA, Irrigation water Requirements, in National Engineering Handbook, SCS, Editor. p. 19-302. 1999. 